\title{
GAMBARAN STATUS KETAKUTAN DAN KECEMASAN TERHADAP PERAWATAN GIGI DI WILAYAH ADMINISTRASI KEPULAUAN SERIBU
}

Lisa Prihastari ${ }^{\star}$, Ahmad Ronal ${ }^{*}$, Mega Octaviani ${ }^{* *}$

\begin{tabular}{c}
\hline Keywords: \\
Dental fear; \\
dental anxiety; \\
sociodemography; \\
MDAS and DFS \\
\hline
\end{tabular}

ABSTRACT

Background: : Most frequent emotional disorders from dental patient are dental fear and anxiety. Previous experiences such as painful tooth extraction, expensive cost, trauma during the last visit to the dentist become factors in the patient's fear of visiting a dentist. Objective: To determine the description of the fear status and anxiety towards dental care in the Kepulauan Seribu Administration area based on age, sex, income, education, insurance, and dental visits.

Method: This study was comparative cross-Sectional analytical research design to determine the relationship between the level of fear and anxiety towards dental care based on sociodemographic factors by giving questionnaires. The tests used were non-parametric and chi-square test.

Results: Based on the results of the chi-square test conducted on 116 respondents aged 17-65 years using the MDAS (Modified Dental Anxiety Scale) test the variables were significantly difference $(P<0.05)$, at group gender and education, while the age variable, income, insurance and visits to the dentist showed no significant difference $(P>0.05)$. The results from Dental Fear Scale variables that were significantly difference were gender and education variables with values $(P<0.05)$, while variable of age, earning, insurance and visits were not significantly difference $(P>0,05)$.

Conclusion: The results can be concluded that gender and education level influence the dental fear and anxiety in the Kepulauan Seribu region

\section{PENDAHULUAN}

Kesulitan dalam menangani pasien dalam hal perawatan gigi tidak hanya dalam prosedur teknis perawatan tetapi juga kesulitan dalam menangani gangguan emosional yang berbeda tiap orangnya. Dalam melakukan perawatan gigi gangguan emosional yang paling sering dialami oleh pasien adalah rasa ketakutan dan kecemasan. ${ }^{1}$ Pengalaman terdahulu yang dialami pasien seperti tindakan pencabutan yang menyakitkan, jumlah tarif yang mahal, trauma dengan pengalaman masa lalu saat berkunjung ke dokter gigi dapat dikatakan menjadi salah satu faktor pasien takut untuk berkunjung ke dokter gigi. Dental fear dan anxiety (DFA) sering dialami pada masa kanak-kanak dan dapat bertahan hingga pasien dewasa, beberapa hal tersebut itulah yang dapat dianggap sebagai alasan pasien enggan untuk kunjungan ke dokter gigi. ${ }^{1}$ Nilai Effective Medical Demand (EMD) yang dimiliki Kepualaun Seribu hanya 8,1\% setara dengan nilai rata-rata Nasional, rendahnya EMD tersebut dimungkinkan karena adanya faktor dental fear dan anxiety namun belum diketahui prevalensi dental fear dan anxiety di Kepulauan Seribu beserta faktor-faktor yang mempengaruhinya.

Berdasarkan pemaparan diatas, maka peneliti ingin melakukan survey epidemiologi untuk mengukur dental fear dan anxiety dengan menggunakan kuesioner DFS dan MDAS serta faktor-faktor sosiodemografi

*Staf Pengajar Program Studi Pendidikan Kedokteran Gigi Fakultas Kedokteran Universitas Yarsi, ** Program Studi Kedokteran Gigi Fakultas Kedokteran Universitas Yarsi

Korespondensi: lisaprihastari@gmail.com 
seperti jenis kelamin, usia, tingkat pendidikan, tingkat ekonomi dan lainnya. Peneliti juga ingin mengetahui faktor apa yang menjadi penyebab dental fear dan anxiety di wilayah Kepulauan Seribu pada rentang usia 17-65 tahun.

Mengetahui gambaran status ketakutan dan kecemasan terhadap perawatan gigi di wilayah Administrasi Kepulauan Seribu dan mengetahui faktor-faktor sosiodemografi yang berhubungan dengan tingkat ketakutan dan kecemasan perawatan gigi tersebut.

\section{METODE PENELITIAN}

Penelitian yang akan digunakan ini penelitian analitik dengan desain penelitian yaitu menggunakan survey Cross Sectional analitik komparatif dan multivariat untuk mengetahui hubungan tingkat ketakutan dan kecemasan terhadap perawatan gigi dengan faktor-faktor sosiodemografi. Populasi dalam penelitian ini adalah seluruh masyarakat asli penduduk setempat dari usia muda 1765 tahun yang berada di wilayah Kabupaten Administrasi Kepulauan Seribu (Pulau Tidung) dengan kriteria inklusi yaitu penduduk asli wilayah Kepulauan Seribu dengan menunjukkan kartu tanda penduduk (KTP), masyarakat dengan kesehatan umumnya baik, sehat jasmani dan rohani, bersedia dan kooperatif menjadi subjek penelitian, bersedia menandatangani informed consent dan bukan wisatawan yang berkunjung. Teknik pengambilan sampel dengan menggunakan metode multistage cluster random sampling terpilih. Besar sampel minimal adalah 83 orang ditambah 9 orang untuk menghindari drop out, maka jumlah sampel ditambahkan $10 \%$ dari hasil perhitungan sampel, tetapi pada penelitian ini, peneliti mengambil data dari 116 responden, Didapatkan hasil yang dipilih yaitu Kepulauan Seribu Selatan setelah itu dilakukan pengundian kembali pulau mana yang harus dikunjungi dan didapatkan hasil Pulau Tidung yang harus dikunjungi dengan teknik random sampling.

Pengumpulan data dilakukan dengan melakukan perizinan terlebih dahulu di Pusat Pelayanan Terpadu Satu Pintu (PTSP) DKI Jakarta dan melakukan izin etik di lembaga etik Universitas Yarsi, lalu dilakukan prosedur translate back translate serta Uji validitas dan reabilitas pada kuesioner DFS dan MDAS menggunakan uji cronbach alpha dan ICC dengan software SPSS 24. Alat dan bahan yang digunakan adalah kuesioner DFS dan MDAS yang telah diartikan ke bahasa Indonesia.

\section{HASIL PENELITIAN}

\section{Hasil Uji Univariat}

Analisis uji variat dilakukan untuk mengetahui gambaran distribusi frekuensi hasil dari penelitian (tabel 1)

Pada tabel 1 menunjukkan nilai distribusi berdasarkan karakteristik responden. Berdasarkan jenis kelamin laki laki berjumlah 57 orang dengan persentase $49,1 \%$ sedangkan responden berjenis kelamin perempuan sebanyak 59 orang dengan persentase $50,9 \%$. Melalui distribusi usia (tahun) dapat dilihat jumlah terbanyak pada usia 17-25 tahun dengan jumlah 52 serta persentasenya $44,8 \%$ dan serta jumlah terendahnya pada usia 56-65 sebanyak 4 responden dengan persentase $3,4 \%$. Pada tingkat pendidikan terakhir responden lulusan SMP paling banyak yaitu 46 responden dengan persentase $39,7 \%$, untuk Iulusan Diploma adalah responden terendah yaitu 1 dengan persentasenya $0,9 \%$. Dari segi penghasilan responden dengan 
Tabel 1. Distribusi frekuensi berdasarkan status sosiodemografi

\begin{tabular}{|c|c|c|}
\hline Variabel & $\mathrm{N}$ & $\%$ \\
\hline \multicolumn{3}{|l|}{ Jenis kelamin } \\
\hline Laki-laki & 57 & 49,1 \\
\hline Perempuan & 59 & 50,9 \\
\hline \multicolumn{3}{|l|}{ Usia (Tahun) } \\
\hline $17-25$ & 52 & 44,8 \\
\hline $26-35$ & 28 & 24,1 \\
\hline $36-45$ & 20 & 17,2 \\
\hline $46-55$ & 12 & 10,3 \\
\hline $56-65$ & 4 & 3,4 \\
\hline \multicolumn{3}{|l|}{ Pendidikan terakhir } \\
\hline Pasca Sajana & - & - \\
\hline Sarjana & 7 & 6,0 \\
\hline Diploma & 1 & 0,9 \\
\hline SMA & 40 & 34,5 \\
\hline SMP & 46 & 39,7 \\
\hline $\mathrm{SD}$ & 20 & 1,72 \\
\hline Tidak sekolah & 2 & 1,7 \\
\hline \multicolumn{3}{|l|}{ Penghasilan } \\
\hline Tidak ada & 46 & 39,7 \\
\hline$<\mathrm{UMR}$ & 49 & 42,2 \\
\hline$\geq$ UMR & 21 & 18,1 \\
\hline \multicolumn{3}{|l|}{ Asuransi } \\
\hline Ya & 103 & 88,8 \\
\hline Tidak & 13 & 11,2 \\
\hline \multicolumn{3}{|l|}{ Kunjungan } \\
\hline $\mathrm{Ya}$ & 45 & 38,8 \\
\hline Tidak & 71 & 61,2 \\
\hline Total & 116 & 100 \\
\hline
\end{tabular}

PERSENTASE DENTAL ANXIETY SCALE

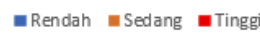

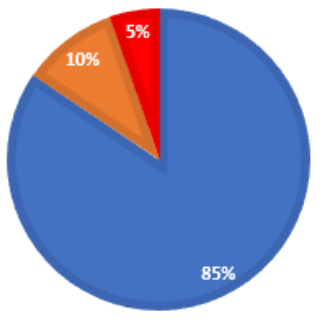

Gambar 1. Persentase Dental Anxiety

pendapatan di bawah UMR (UMR= Rp. $3,400,000 .-)$ yaitu terbanyak sebesar 49 orang besar persentasenya 42,2\%, responden yang mendapatkan penghasilan diatas UMR

\section{PERSENTASE DENTAL FEAR}

- Takut =Sedikit Takut - Sangat Takut

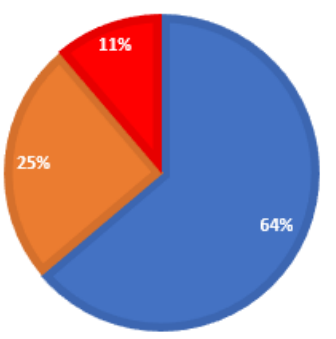

Gambar 2. Persentase Dental Fear

sebanyak 21 dengan persentasenya 18,1\%. Banyak responden yang telah memiliki asuransi sebanyak 103 dengan jumlah persentase $88,8 \%$, dan yang tidak memiliki 
asuransi 13 responden jumlah persentasenya yaitu $11,2 \%$. Jumlah kunjungan didapatkan jumlah 45 responden yang pernah ke dokter gigi dengan persentasenya $38,8 \%$ dan untuk yang belum pernah ke dokter gigi sebanyak 71 responden dengan persentasenya $61,2 \%$.

Pada diagram presentase rasa cemas gambar 1, menunjukan dari 116 responden yang mengikuti penelitian, jumlah responden yang memiliki rasa cemas rendah terhadap perawatan gigi sebanyak 98 orang (85\%), 12 orang $(10 \%)$ memiliki rasa cemas sedang, dan 6 orang $(5 \%)$ memiliki rasa cemas tinggi.

Pada diagram presentase rasa takut gambar 2 dapat disimpulkan bahwa dari 116 responden yang mengikuti penelitian, jumlah responden yang takut terhadap perawatan gigi sejumlah 74 orang (64\%), responden yang sedikit takut terhadap perawatan gigi sejumlah 29 orang $(25 \%)$, dan responden yang sangat takut terhadap perawatan gigi sejumlah 13 orang $(11 \%)$.

\section{Hasil Uji Bivariat}

Analisis Bivariat dilakukan untuk menghubungkan variabel independen dan dependen (tabel 2).

Pada tabel 2 uji non parametrik MDAS

Tabel 2. Hasil uji non parametrik MDAS

\begin{tabular}{|c|c|c|c|c|}
\hline Variabel & $\begin{array}{c}\text { MDAS } \\
\text { Mean } \pm \text { SD }\end{array}$ & P Value & $\begin{array}{c}\text { DFS } \\
\text { Mean } \pm \text { SD }\end{array}$ & P Value \\
\hline \multicolumn{5}{|l|}{ Jenis kelamin } \\
\hline Laki-laki & $10,14 \pm 3,55$ & 0,042 & $31,70 \pm 9,70$ & 0,001 \\
\hline Perempuan & $11,85 \pm 4,30$ & & $39,42 \pm 14,60$ & \\
\hline \multicolumn{5}{|l|}{ Usia (Tahun) } \\
\hline $17-25$ & $10,69 \pm 3,46$ & & $34,40 \pm 9,90$ & \\
\hline $26-35$ & $11,25 \pm 4,40$ & 0,787 & $36,39 \pm 14,00$ & 0,835 \\
\hline $36-45$ & $10,40 \pm 3,70$ & & $33,05 \pm 9,00$ & \\
\hline $46-55$ & $13,00 \pm 6,00$ & & $44,83 \pm 22,96$ & \\
\hline $56-65$ & $11,00 \pm 2,90$ & & $32,75 \pm 10,70$ & \\
\hline \multicolumn{5}{|l|}{ Pendidikan terakhir } \\
\hline Pasca Sajana & - & & - & \\
\hline Sarjana & $10,29 \pm 2,20$ & & $33,00 \pm 11,20$ & \\
\hline Diploma & - & 0,148 & - & 0,098 \\
\hline SMA & $11,00 \pm 3,90$ & & $36,80 \pm 13,30$ & \\
\hline SMP & $10,78 \pm 3,70$ & & $33,83 \pm 10,30$ & \\
\hline $\mathrm{SD}$ & $10,85 \pm 3,80$ & & $34,95 \pm 10,60$ & \\
\hline Tidak sekolah & - & & $81,00 \pm 14,10$ & \\
\hline \multicolumn{5}{|l|}{ Penghasilan } \\
\hline Tidak ada & $10,70 \pm 3,60$ & & $34,20 \pm 10,10$ & \\
\hline$<$ UMR & $11,63 \pm 4,70$ & 0,611 & $37,63 \pm 15,85$ & 0,888 \\
\hline$\geq \mathrm{UMR}$ & $10,33 \pm 3,60$ & & $34,43 \pm 11,00$ & \\
\hline \multicolumn{5}{|l|}{ Asuransi } \\
\hline $\mathrm{Ya}$ & $11,09 \pm 4,06$ & 0,670 & $36,21 \pm 13,13$ & 0,160 \\
\hline Tidak & $10,54 \pm 3,80$ & & $31,54 \pm 11,40$ & \\
\hline \multicolumn{5}{|l|}{ Kunjungan } \\
\hline $\mathrm{Ya}$ & $10,37 \pm 3,40$ & 0,052 & $34,17 \pm 10,48$ & 0,376 \\
\hline Tidak & $12,07 \pm 4,20$ & & $38,09 \pm 16,00$ & \\
\hline
\end{tabular}

Keterangan: Uji chi-square; $p<0,05=$ terdapat hubungan yang bermakna. 
pada variabel jenis kelamin diketahui bahwa perempuan nilai rata-ratanya lebih tinggi dari pada laki-laki dengan skor MDAS sebesar $11,85 \pm 4,30$ dengan hasil uji signifikansinya yaitu $p=0,042(p<0,05)$ yang berarti terdapat perbedaan yang bermakna antara kelompok jenis kelamin, dan pada skor DFS juga didapatkan nilai rata-rata yang lebih besar dibandingkan laki-laki yaitu 39,42 $\pm 14,60$ dengan nilai signifikansi yang terdapat adanya perbedaan bermakna pada uji signifikan antara kelompok usia dengan nilai $p=0,001$ $(p<0,05)$. Pada variabel penelitian usia, nilai rata-rata skor MDAS tertinggi terdapat pada kelompok usia 46-55 tahun dengan ratarata skor 13,00 $\pm 6,00$ pada uji signifikansi menunjukkan tidak ada perbedaan bermakna antara kelompok usia dengan nilai $p=0,787$ $(p<0,05)$. Pada skor DFS, rata-rata skor tertinggi terdapat pada kelompok usia yang sama yaitu 46-55 tahun dengan rata-rata $44,83 \pm 22,96$ dengan nilai $p=0,835(p<0,05)$ menandakan bahwa tidak terdapat perbedaan bermakna antara kelompok usia.

Berdasarkan tingkatan pendidikan, ratarata skor MDAS tertinggi terdapat pada kelompok pendidikan SMA dengan skor ratarata $11,00 \pm 3,90$ hasil dari uji signifikansinya $p=0,148 \quad(p<0,05)$ berarti tidak terdapat perbedaan bermakna antara tingkatan kelompok pendidikan, sedangkan untuk skor DFS, rata-rata tertinggi berdasarkan pendidikan terdapat pada tidak sekolah dengan nilai rata-rata skor $81,00 \pm 14,10$ dan uji signifikansinya menunjukkan tidak terdapat perbedaan bermakna antara kelompok pendidikan dengan nilai $p=0,098(p<0,05)$.

Hasil yang didapatkan dari penghasilan menunjukkan rata-rata MDAS tertinggi pada penghasilan <UMR yaitu dengan hasil uji signifikan 11,63 $\pm 4,70$, menunjukkan nilai $p=0,611(p<0,05)$ dapat dikatakan uji signifikansi tidak terdapat perbedaan bermakna antara kelompok penghasilan. Pada hasil uji MDAS responden yang memiliki asuransi sebanyak $11,09 \pm 4,06$ dengan uji nilai $p=0,670$ $(p<0,05)$ menujukkan tidak terdapat perbedaan bermakna antara kelompok penghasilan. Berdasarkan kepemilikan asuransi skor MDAS menunjukkan rata-rata skor yang lebih tinggi pada responden yang memiliki asuransi $11,09 \pm 4,06$, dengan nilai hasil uji signifikansi $p=0,670(p<0,05)$ yang artinya tidak terdapat perbedaan yang bermakna antara kelompok asuransi, dan untuk rata-rata nilai skor DFS lebih tinggi pada responden yang memiliki asuransi 36,21 $\pm 13,13$ dibandingkan yang tidak memiliki asuransi, dengan nilai uji signifikansi $p=0,160 \quad(p<0,05)$ berarti tidak terdapat perbedaan yang bermakna antara kelompok asuransi. Berdasarkan hasil pertanyaan kunjungan ke dokter gigi yang telah diolah nilai rata-rata MDASnya didapatkan hasil lebih tinggi pada responden yang tidak pernah ke dokter gigi $10,37 \pm 3,40$ dibandingkan yang pernah ke dokter gigi dengan hasil uji signifikansi $p=0,052(p<0,05)$ menunjukkan tidak terdapat perbedaan bermakna antara responden yang pernah ke dokter gigi dan tidak, sedangkan untuk nilai rata-rata skor DFSnya lebih tinggi responden yang tidak pernah berkunjung ke dokter gigi yaitu sebesar 38,09 $\pm 16,00$ dengan nilai uji signifikansi sebesar $p=0,376(p<0,05)$ yang menunjukkan juga tidak terdapat perbedaan bermakna antara kelompok usia yang pernah berkunjung ke dokter gigi atau tidak.

Berdasarkan dari penelitian yang telah dilakukan, untuk proporsi tingkat kecemasan berdasarkan jenis kelamin, responden dengan kecemasan tinggi terbesar ada pada perempuan dengan persentase 
Tabel 3. Hasil uji Chi-Square berdasarkan status sosiodemografi

\begin{tabular}{|c|c|c|c|c|c|c|c|c|}
\hline \multirow[b]{2}{*}{ Variabel } & \multicolumn{4}{|c|}{ Dental Anxiety } & \multicolumn{4}{|c|}{ Dental Fear } \\
\hline & Rendah & Sedang & Tinggi & $\begin{array}{c}P \\
\text { Value }\end{array}$ & $\begin{array}{l}\text { Tidak } \\
\text { Takut }\end{array}$ & $\begin{array}{c}\text { Sedikit } \\
\text { Takut }\end{array}$ & $\begin{array}{c}\text { Sangat } \\
\text { Takut }\end{array}$ & $\begin{array}{c}P \\
\text { Value }\end{array}$ \\
\hline \multicolumn{9}{|l|}{ Jenis kelamin } \\
\hline Laki-laki & $50,0 \%$ & $58,3 \%$ & $0,0 \%$ & 0,045 & $59,5 \%$ & $31,0 \%$ & $23,1 \%$ & 0,005 \\
\hline Perempuan & $50,0 \%$ & $41,7 \%$ & $100,0 \%$ & & $40,5 \%$ & $69,0 \%$ & $76,9 \%$ & \\
\hline \multicolumn{9}{|l|}{ Usia (Tahun) } \\
\hline $17-25$ & $44,9 \%$ & $58,3 \%$ & $16,7 \%$ & & $44,6 \%$ & $55,2 \%$ & $23,1 \%$ & \\
\hline $26-35$ & $23,5 \%$ & $16,7 \%$ & $50.0 \%$ & & $24,3 \%$ & $20,7 \%$ & $30,8 \%$ & \\
\hline $36-45$ & $18,4 \%$ & $16,7 \%$ & $0,0 \%$ & 0,378 & $18,9 \%$ & $17,2 \%$ & $7,7 \%$ & 0,052 \\
\hline $46-55$ & $9,2 \%$ & $8,3 \%$ & $33,3 \%$ & & $8,1 \%$ & $3,4 \%$ & $38,5 \%$ & \\
\hline $56-65$ & $4,1 \%$ & $0,0 \%$ & $0,0 \%$ & & $4,1 \%$ & $3,4 \%$ & $0,0 \%$ & \\
\hline \multicolumn{9}{|l|}{$\begin{array}{l}\text { Pendidikan } \\
\text { terakhir }\end{array}$} \\
\hline Pasca Sajana & - & - & - & & - & - & - & \\
\hline Sarjana & $7,1 \%$ & $0,0 \%$ & $0,0 \%$ & & $6,8 \%$ & $3,4 \%$ & $7,7 \%$ & \\
\hline Diploma & $1,0 \%$ & $0,0 \%$ & $0,0 \%$ & 0,000 & $1,4 \%$ & $0,0 \%$ & $0,0 \%$ & 0,046 \\
\hline SMA & $34,7 \%$ & $41,7 \%$ & $16,7 \%$ & & $32,4 \%$ & $37,9 \%$ & $38,5 \%$ & \\
\hline SMP & $38,8 \%$ & $50,0 \%$ & $33,3 \%$ & & $43,2 \%$ & $37,9 \%$ & $23,1 \%$ & \\
\hline $\mathrm{SD}$ & $18,4 \%$ & $8,3 \%$ & $16,7 \%$ & & $16,2 \%$ & $20,7 \%$ & $15,4 \%$ & \\
\hline $\begin{array}{l}\text { Tidak } \\
\text { sekolah }\end{array}$ & $0,0 \%$ & $0,0 \%$ & $33,3 \%$ & & $0,0 \%$ & $0,0 \%$ & $15,4 \%$ & \\
\hline \multicolumn{9}{|l|}{ Penghasilan } \\
\hline Tidak ada & $39,8 \%$ & $50,0 \%$ & $16,7 \%$ & & $41,9 \%$ & $44,8 \%$ & $15,4 \%$ & \\
\hline$<\mathrm{UMR}$ & $40,8 \%$ & $33,3 \%$ & $83,3 \%$ & 0,289 & $39,2 \%$ & $37,9 \%$ & $69,2 \%$ & 0,304 \\
\hline$\geq \mathrm{UMR}$ & $19,4 \%$ & $16,7 \%$ & $0,0 \%$ & & $18,9 \%$ & $17,2 \%$ & $15,4 \%$ & \\
\hline \multicolumn{9}{|l|}{ Asuransi } \\
\hline Ya & $89,8 \%$ & $75,0 \%$ & $100 \%$ & 0,207 & $86,5 \%$ & $93,1 \%$ & $92,3 \%$ & 0,577 \\
\hline Tidak & $10,2 \%$ & $25,0 \%$ & $0,0 \%$ & & $13,5 \%$ & $6,9 \%$ & $7,7 \%$ & \\
\hline \multicolumn{9}{|l|}{ Kunjungan } \\
\hline $\mathrm{Ya}$ & $65,3 \%$ & $41,7 \%$ & $33,3 \%$ & 0,101 & $62,2 \%$ & $69,0 \%$ & $38,5 \%$ & 0,166 \\
\hline Tidak & $34,7 \%$ & $58,3 \%$ & $66,7 \%$ & & $37,8 \%$ & $31,0 \%$ & $61,5 \%$ & \\
\hline
\end{tabular}

hingga seluruhnya yaitu $100 \%$ dengan nilai uji signifikansinya menunjukkan adanya perbedaan yang bermakna antara kelompok jenis kelamin dengan nilai $p=0,045(p<0,05)$, untuk responden dengan ketakutan yang sangat takut ada pada jenis kelamin perempuan juga dengan persentase 76,9\% nilai uji signifikannya $p=0,005(p<0,05)$ yang artinya ada perbedaan bermakna antara kelompok usia. Dalam kategori usia, proporsi dengan tingkat keceemasan tinggi ada pada kelompok usia 26-35 tahun dengan persentase $50,0 \%$ dengan nilai $p=0,378(p<0,05)$ hasil uji signifikansinya menunjukkan tidak adanya perbedaan bermakna antara kelompok usia, responden yang sangat takut pada tingkat ketakutan ada pada kelompok usia 46-55 tahun dengan persentase $38,5 \%$ dan memiliki nilai $p=0,052(p<0,05)$ yang menunjukkan hasil uji signifikansinya tidak adanya perbedaan 
bermakna antara kelompok usia.

Hasil uji signifikansi pada tingkatan Pendidikan terakhir dengan kecemasan tinggi ada pada responden tingkatan SMP dan responden yang tidak sekolah dengan persentase $33,3 \%$ dengan nilai rata-rata $p=0,000 \quad(p<0,05)$ hasil uji signifikannya menunjukkan adanya perbedaan bermakna antara kelompok Pendidikan, untuk responden yang sangat takut ada pada tingkatan SMA sebesar $38,5 \%$ didapatkan nilai $p=0,046$ $(p<0,05)$ nilai ini menunjukkan adanya perbedaan bermakna antar kelompok Pendidikan.

Kategori penghasilan didapatkan tingkatan kecemasan tinggi terbesar terdapat pada responden yang mendapatkan penghasilan $<$ UMR dengan persentase $83,3 \%$ nilai $p=0,289$ $(p<0,05)$ menunjukkan tidak ada perbedaan bermakna antara kelompok penghasilan, sedangkan responden dengan kategori sangat takut terbesar sama halnya yaitu penghasilan <UMR sebesar $69,2 \%$ nilai rata-ratanya $p=0,304(p<0,05)$ menunjukkan tidak adanya perbedaan bermakna antara kelompok penghasilan.

Menurut kelompok ada tidaknya asuransi tingkat kecemasan tinggi terbesar pada kelompok yang memiliki asuransi sebesar $100 \%$ dengan nilai rata-rata $p=0,207(p<0,05)$ hasil ini menunjukkan tidak ada perbedaan yang bermakna antara kelompok asuransi, pada responden yang sangat takut proporsi terbesar ada pada kelompok responden yang memiliki asuransi juga sebesar 92,3\% dengan nilai $p=0,577(p<0,05)$ menunjukkan nilai signifikansi yang tidak ada perbedaan yang bermakna antara kelompok asuransi. Berdasarkan kunjungan pernah ke dokter gigi responden yang tidak pernah ke dokter gigi lebih tinggi persentase tingkat kecemasannya yaitu $66,7 \%$ dengan jumlah nilai $p=0,101$ $(p<0,05)$ yang artinya tidak ada perbedaan yang bermakna antara kelompok kunjungan, dalam penilaian DFS sangat takut yang belum pernah berkunjung ke dokter gigi tinggi nilai persentasenya sebesar $61,5 \%$ dengan nilai $p=0,166 \quad(p<0,05)$ menunjukkan signifikansi nilai rata-rata tidak ada perbedaan bermakna antara kelompok kunjungan.

\section{DISKUSI}

\section{Jenis Kelamin}

Hasil penelitian menunjukkan, berdasarkan jenis kelamin perempuan lebih cemas dan takut terhadap perawatan gigi hingga menunjukkan persentase $100 \%$ untuk dental anxiety dan untuk dental fear didapatkan hasil $76,9 \%$. Hal ini sejalan dengan penelitian yang dilakukan oleh Luoto A dkk (2014). ${ }^{2}$ Ter Horst dan Wit juga mengatakan bahwa perempuan lebih cemas dibandingkan laki-laki (Alaki, 2011). ${ }^{3}$ Penelitian yang dilakukan di negara Brazil diteliti oleh Ricardo Wathson Feitosa de Carvalho (2013) juga menunjukkan hasil perempuan lebih takut dibandingkan lakilaki dengan jumlah sampel 340 responden dan hampir dari setengahnya didominasi oleh perempuan. ${ }^{4}$ Berdasarkan jenis kelamin perempuan lebih cemas dibandingkan lakilaki, hal ini serupa dengan penemuan Acharya pada populasi di India dikatakan hal tersebut terjadi karena perempuan lebih mampu mengakui kecemasan yang dialami dan lebih rentan terhadap gangguan kecemasan. Asumsi lain dari penelitian inidapat dijelaskan dengan asumsi perempuan mengalami tingkat neuroticism yang lebih tinggi daripada laki-laki. Neuroticism adalah menggambarkan kondisi manusia yang memiliki masalah dengan emosi yang negative seperti rasa khawatir dan rasa 
tidak aman. Pada umumnya perempuan lebih berfikir dengan perasaan dibandingkan lakilaki. $^{3}$

\section{Usia}

Pada uji MDAS pada kategori usia didapatkan yang mengalami kecemasan tinggi yaitu pada usia 26-35 tahun, sedangkan uji ketakutan DFS pada usia 46-55 tahun dan usia setelahnya yaitu 56-65 tahun kembali sesuai dengan penelitian lainnya Appukuttan dan Datchnamurthy (2016) yaitu tingkat kecemasannyalebihrendah dikarenakanseiring bertambahnya usia, yang mungkin dikaitkan dengan degenerasi otak, faktor ekstrinsik maupun kebiasaan serta pengalaman yang lebih dahulu mereka alami. ${ }^{5}$ Angka ketakutan dan kecemasan diusia muda juga didapatkan hasil pada penelitian Tuba Talo Yildrim, Serkan Dundar, Alihan Bozoglan dan lainnya di negara Turki (2017) menujukkan individu dengan usia muda 15-25 tahun memiliki sedikit ketakutan terhadap dokter gigi dibanding individu usia tua hasil tersebut bernilai sama, dengan hasil dari penelitian yang peneliti dapatkan usia 17-25 tahun berada pada persentase Dental Anxiety sedang (58,3\%) dan Dental Fear sedikit takut $(55,2 \%) .{ }^{6}$ Pada penelitian lainnya yang dilakukan oleh Fitriani Riksavianti dan Rasmindar Samad di Indonesia (2014) didapatkan hasil yang sama dengan penelitian peneliti yaitu pada usia 26-35 tahun memiliki rata-rata skor kecemasan tertinggi. ${ }^{7}$ Penelitian yang dilakukan oleh Mawa 2013 menyatakan bahwa pasien dewasa muda (awal) lebih labil dalam menghadapi suatu hal tertentu yang dapat membuat mereka tertekan, dalam sebuah jurnal International Medical Association Bulgaria pada tahun 2011 Kirova, berpendapat berdasarkan data statistik dikatakan bahwa usia 25-26 tahun merupakan usia dimana seseorang mengalami kecemasan dental yang paling tinggi. (Mawa, 2013) ${ }^{8}$, sementara responden yang berusia 56-65 tahun memiliki rata-rata skor terendah sama halnya dengan penelitian Appukuttan dan Datchnamurthy (2016) Melaporkan bahwa individu yang berusia lebih lanjut memiliki tingkat kecemasan yang lebih rendah dikatakan bahwa penurunan tingkat kecemasan terhadap perawatan gigi dapat disebabkan penurunan kecemasan secara umum dan paparan yang lebih besar untuk penyakit lain dan terapinya. ${ }^{5}$

\section{Pendidikan Terakhir}

Tingkatan Pendidikan terakhir responden dari penelitian ini didapatkan hasil yang memiliki kecemasan tinggi berada dengan Pendidikan terakhir SMP dan tidak bersekolah dengan jumlah persentase yang seimbang yaitu $(33,3 \%)$ dan responden yang memiliki persentase sangat takut ada pada Pendidikan SMA sebesar (38,5\%). Hasil tersebut serupa dengan penelitian yang dilakukan oleh Acharya (2008) dan Peretz (2000) menyatakan mereka yang tidak berpendidikan relative lebih cemas dari mereka yang berpendidikan, sebab didapatkan fakta responden yang berpendidikan lebih tinggi mampu mengatasi stress lebih baik dengan rasionalisasi situasi. ${ }^{3,9}$ Pakpour dkk (2014) berkata orang dengan tingkat pendidikan lebih tinggi pada umumnya lebih peduli dengan keberadaan pelayanan kesehatan, dan mencari informasi tentang pelayanan kesehatan gigi dan praktek-praktek dokter gigi. ${ }^{10}$ Yildrim (2016) menyatakan beberapa penelitian ditemukan bahwa individu dengan rendah keduanya yaitu ekonomi dan Pendidikan rendah itu lebih cemas. ${ }^{6}$

\section{Penghasilan}

Jumlah penghasilan responden di 
Kepulauan Tidung didominasi pada penghasilan kurang dari UMR (Rp 3.400.000) pada responden yang mengalami kecemasan tinggi dan sangat takut. Hasil seperti ini juga didapatkan pada penelitian Armfield (2006) melaporkan bahwa orang dengan latar belakang sosial ekonomi rendah memiliki kesehatan fisik yang lebih rendah, masalah psikologis dan kurangnya akses pelayanan kesehatan sehingga lebih cemas terhadap perawatan gigi. ${ }^{6}$ Pada beberapa penelitian ditemukan bahwa sesorang yang memiliki status ekonomi rendah dan tingkat pendidikan yang rendah lebih memiliki rasa kecemasan yang tinggi (Yildrim, 2016). ${ }^{5}$ Didapatkan dari sebuah penelitian yang dilakukan oleh Berghdal (2012) dikatakan masyarakat yang status ekonominya rendah cenderung lebih takut dan cemas terhadap perawatan gigi dibandingkan dengan masyarakat yang social ekonominya menengah ke atas. Hal ini dikarenakan kurang umum bagi masyarakat yang status ekonominya rendah. ${ }^{11}$

\section{Asuransi}

Negara Indonesia memiliki 2 jenis asuransi kesehatan, baik itu asuransi nasional maupun pihak swasta. Asuransi Nasional adalah asuransi yang dimiliki negara yang biasanya disebut Jaminan Kesehatan Nasional, dan dikelola oleh badan penyelenggara Jaminan Kesehatan Sosial (BPJS Kesehatan), peserta asuransi ini adalah setiap orang yang berada di Indonesia, termasuk pekerja asing yang telah bekerja lebih dari 6 bulan di Indonesia, kepesertaan ini sendiri tebagi menjadi dua kelompok, yaitu kelompok penerima bantuan iuran jaminan kesehatan dan bukan penerima bantuan iuran kesehatan, serta memiliki manfaat yang cukup lengkap yaitu mencakup pelayanan kesehatan tingkat pertama hingga lanjutan, termasuk didalamnya perawatan gigi dan mulut juga sebagai tanggungannya, selain itu terdapat program pemerintah yang bernama Kartu Jakarta Sehat (KJS), program ini terpusat pada warga DKI Jakarta yang kurang mampu, manfaat dan penyelenggaraan program ini juga sama dan dilakukan oleh BPJS kesehatan. Asuransi lain yang terdapat di Indonesia adalah asuransi swasta, manfaat dan penyelenggaraan dari asuransi jenis ini berbeda-beda tergantung perusahaan dan premi asurnasi yang dibayarkan. Namun pada penelitian ini, peneliti tidak melihat jenis asuransi yang digunakan oleh responden. ${ }^{12,13}$

Pada penelitian ini ditemukan tidak terdapat perbedaan signifikan pada tingkat kecemasan dan ketakutan responden yang memiliki asuransimaupun tidak, adapun respondenyang tidak memiliki asuransi memiliki rata-rata skor takut dan cemas yang lebih rendah dibanding responden yang memiliki asuransi kesehatan. Pada penelitian lain yang dilakukan oleh Armfield dkk di negara Australia, didapatkan bahwa adanya perbedaan signifikan antara responden yang memiliki asuransi pribadi dan responden yang tidak memiliki asuransi pribadi, dimana tingkat ketakutan yang lebih tinggi terdapat pada responden yang tidak memiliki asuransi pribadi, akan tetapi ketika masalah gigi dan mulut berhasil di kontrol, hanya terdapat sedikit perbedaan tingkat ketakutan antara responden yang memiliki asuransi atau tidak memiliki.

\section{Kunjungan ke dokter gigi}

Pada hasil penelitian responden yang tidak pernah berkunjung ke dokter gigi sangat tinggi rasa kecemasannya serta sangat takut untuk melakukan perawatan. Dalam penelitiannya Sheetal (2011) menyatakan responden yang kesehatan mulutnya buruk lebih cemas 
daripada responden yang kesehatan mulutnya baik. ${ }^{14}$ Perihal kunjungan kedokter gigi erat hubungannya dengan masalah ekonomi dikatakan oleh Berghdal (2012) dikarenakan perawatan gigi bukan hal biasa bagi masyarakat yang status ekonominya rendah hal tersebut membuat masyarakat dengan lebih cemas. ${ }^{11}$ Pada penelitian yang peneliti lakukan didapatkan responden sebanyak 116 responden dan banyak dari setengahnya belum pernah berkunjung atau mendapatkan perawatan gigi dan mulut sejumlah 71 orang dengan persentase $61,2 \%$, ada beberapa faktor yang dapat menimbulkan kecemasan diantaranya yaitu mendengarkan pengalaman dari orang lain yang hanya pengalaman subjektif yang dirasakan, seperti teman dan anggota keluarganya yang sudah pernah melakukan perawtan gigi seperti ekstraksi gigi atau kurangnya pengetahuan maupun informasi mengenai perawatan yang akan dilakukan.

\section{KESIMPULAN}

Terdapat perbedaan signifikan antara usia dan tingkat pendidikan, dan tidak ada perbedaan signifikan antara kecemasan maupun dan ketakutan dengan faktor sosiodemografi lainnya.

\section{DAFTAR PUSTAKA}

1. Arlette Suzy S, Aplikasi teori belajar social dalam penatalaksanaan rasa takut dan cemasan anak pada perawatan gigi. Dental Journal Majalah Kedokteran Gigi. Vol 47, no 2, June 2014; hal. 87, Bandung.

2. Luoto A, Tolvanen M, Rantavuori K, Pohjola V, Karlsson L \& Lahti S, 2014. Individual changes in dental fear among children and parents: A longitudinal study. Acta Odontologica Scandinavica. Jan: hal 942-947.
3. Acharya S. Factor affecting dental anxiety and beliefs in an Indian population. $\mathrm{J}$ oral Rehabil 2008;35:259-67.

4. Wathson R.F, Germano P, Jose G 2013. Prevalence and predictive factors of Dental anxiety in Brazilian Adolescents. Brazil Feb: hal.41-46.

5. Appukuttan D, Datchnamurthy M, Deborah SP, Hirudaraj GJ, Tadepelli A, Victor DJ. Reliability and validity of the Tamil version of modified dental anxiety scale. J Oral Sci 2012;(4):313-20.

6. Talo Yildirim T, Dundar S, Bozoglan A,Karaman $T$, Dildes $N$, Acun Kaya $F$, et al. Is there a relation between dental anxiety, fear and general psychological status?PeerJ [Internet]. 2017;5:2. Available from: https://peerj.com/articles/2987.

7. A.H. Schuurs and J. Hoogstraten, "Appraisal of dental anxiety and fear questionnaires: a review," Community Dentistry and Oral Epidemiology, vol.21, no. 6, 1993;pp. 329-339

8. Mawa MAC, Manado. Kandou LFJ, Anindita PS. Gambaran tingkat kecemasan pasien usia dewasa pra tindakan pencabutan gigi di Balai Pengobatan Rumah Sakit Gigi dan Mulut. eG 2013; 1(2)

9. Peretz B, Efrat J. Dental anxiety among young adolescent patients in Israel. Int J Paediatr Dent 2000;10:126-32.

10. Pakpour AH, Gellert P, Asefzadeh S, Sniehotta FF. 2014. Planning predicts dental service attendance and the effect is moderated by dental anxiety and educational status: findings from a one-year prospective study. Applied Psychology: Health and Well-Being 6:214-229 DOI 10.1111/ APHW.12025.

11. Berghdal J. 2012. Clinical management of the adults patient with dental anxiety. Thesis. Tromso: Masteroppgave klinik odontology. P.4-6.

12. Kementerian Kesehatan Republik Indonesia. Peraturan Menteri Kesehatan. 71 Indonesia; 2013. Diunduh 27 Januari 2018. Pukul 10.16 WIB. Jakarta.

13. Rudi A. Apa Perbedaan KIS, KJS, JKN, dan BPJS Kesehatan? [Internet]. 2014 [cited 2018 Jan 18]. Available from: http://megapolitan.kompas.com/ read/2014/11/04/15221551/Apa.Perbedaan.KIS. KJS.JKN.dan.BPJS.Kesehatan. Diunduh 27 Januari 2018. Pukul 10.30 WIB. Jakarta.

14. Sheetal S, Agrawal P, Patil S. Realitionship between dental anxiety and pain perception during sealing. J Oral Ser 2011;53(3):341-8. 